\title{
Influence of Stubble Height and Nitrogen Fertilizer Level on Seed Yield and Quality in KRH-4 Hybrid Rice Seed Production
}

\author{
Madhukeshwara B. Puttappanavara* and V.K. Deshpande \\ Department of Seed Science and Technology, College of Agriculture, University of \\ Agricultural Sciences, Dharwad, Karnataka State (India)-580005 \\ *Corresponding author
}

\section{Keywords}

Stubble height,

Ratooning,

Nitrogen, Hybrid

Article Info

Accepted:

04 March 2019

Available Online:

10 April 2019

\section{A B S T R A C T}

A field experiment was carried out during rabi 2016 and 2017 at the Agricultural Research Station, Malagi, UAS, Dharwad to study the influence of stubble height and nitrogen fertilizer level on ratoon seed yield in KRH-4 hybrid rice seed production. The experiment consisted of two factors. Factor one was the stubble height which included 3 cutting heights namely $\mathrm{H}_{1:}(15 \mathrm{~cm} A$ line and $15 \mathrm{~cm} \mathrm{R}$ line $), \mathrm{H}_{2:}(15 \mathrm{~cm}$ A line and $20 \mathrm{~cm} \mathrm{R}$ line $)$ and $\mathrm{H}_{3:}(20 \mathrm{~cm}$ A line and $20 \mathrm{~cm} \mathrm{R}$ line). Factor two was the nitrogen fertilizer levels viz., $\mathrm{F}_{1}:\left(25 \% \mathrm{~N}\right.$ of main crop), $\mathrm{F}_{2}:\left(50 \% \mathrm{~N}\right.$ of main crop), $\mathrm{F}_{3}:\left(75 \% \mathrm{~N}\right.$ of main crop) and $\mathrm{F}_{4}$ : (100\% $\mathrm{N}$ of main crop) and the treatment combinations were replicated thrice. The results revealed that among the stubble heights $\mathrm{H}_{3}$ recorded the highest regeneration percentage ( $98.89 \%$ and $98.67 \%$ in 2016 and 2017 respectively), highest plant height (45.54 cm and $46.54 \mathrm{~cm}$ in 2016 and 2017 respectively), whereas the highest seed set $(8.47 \%$ and $8.68 \%$ in 2016 and 2017 respectively) and seed yield per hectare (375 kg and $425 \mathrm{~kg}$ in 2016 and 2017 respectively) recorded by $\mathrm{H}_{2}$. Among the nitrogen levels $\mathrm{F}_{4}$ recorded the highest regeneration (97.49\% and $97.53 \%$ in 2016 and 2017 respectively) and highest plant height (44.50 cm and $45.61 \mathrm{~cm}$ in 2016 and 2017 respectively) whereas the $F_{3}$ recorded highest seed yield per hectare ( $395 \mathrm{~kg}$ and $450 \mathrm{~kg}$ in 2016 and 2017 respectively). Among the combinations $\mathrm{H}_{2} \mathrm{~F}_{3}$ recorded the highest seed yield per hectare (449 $\mathrm{kg}$ and $502 \mathrm{~kg}$ in 2016 and 2017 respectively) due to effective synchrony of flowering between the parental lines. The study indicated that stubble height at $\mathrm{H}_{2:}(15 \mathrm{~cm}$ A line and $20 \mathrm{~cm} \mathrm{R}$ line) together with nitrogen fertilizer level of $\mathrm{F}_{3}$ : (75\% $\mathrm{N}$ of main crop) is ideal in achieving the better synchrony of flowering as well as better regeneration of ratoon to get higher seed yield in KRH-4 hybrid rice.

\section{Introduction}

Rice (Oryza sativa L.) is the staple food for nearly fifty per cent of the world's population. Rice ratooning is the production of a second rice crop from the stubble left behind after the main-crop harvest. The ratoon crop develops by regenerating rice tillers from nodal buds of the stubble that was left behind after the first seasonal rice harvest. The practice of ratooning can be followed by the farmers for the purpose of on farm seed production which 
ensures cent per cent genetic purity in seed production activity as the ratoons are generated vegetatively. Grain yield of the ratoon crop is generally one-third of the yield realized in the first, or main, crop (Turner and Jund, 1993). Main-crop harvest heights are cultivar dependent and generally range between 40 and $45 \mathrm{~cm}$ above ground level. Lower harvest heights leaving stubble of 20$25 \mathrm{~cm}$ are currently recommended in Texas as a potential ratoon yield enhancement strategy when the main crop is harvested before August 15 (Tarpley et al., 2008). The advantage of rice ratooning is that in areas where rice is the main crop, a double crop of rice can be grown for additional returns. The ratoon crop matures earlier and requires less labor and water inputs (Reddy et al, 1979). Rice ratooning offers special scope for increasing production without expanding land area, particularly where moisture and growing season are inadequate for planting a second crop of rice. The practice of ratooning in hybrid rice ensures the cent per cent of genetic purity in hybrid rice seed production as the ratooning involves the vegetative propagation of parental lines through the left over stubbles. Seed production from the ratoon crop may thus be possible. Planting value and stability of ratoon crop seed are worth studying to determine the seed production potential. In case of scarcity of parental seeds and human resource $F_{1}$ seed production can be made possible with small alterations in agronomic practices to obtain considerable quantity of $\mathrm{F}_{1}$ seeds within short span of time with least effort. This practice also reduces burden of rouging, weeding, isolation maintenance which have been taken care of during main crop only. Hence the effort was made to realize the importance of technique.

\section{Materials and Methods}

The field experiment was carried out at the Agricultural Research Station Malagi, UAS,
Dharwad during rabi 2016 and 2017 to standardize the technique of hybrid rice seed production through ratooning of parental lines in KRH-4 hybrid rice. The experiment was laid out in randomized block design with 2 factors viz., factor one consisted of the height of stubble cutting $\left(\mathrm{H}_{1}\right): 15 \mathrm{~cm}$ A line and 15 $\mathrm{cm} \mathrm{R}$ line, $\left(\mathrm{H}_{2}\right): 15 \mathrm{~cm} \mathrm{~A}$ line and $20 \mathrm{~cm} \mathrm{R}$ line, $\left(\mathrm{H}_{3}\right): 20 \mathrm{~cm} \mathrm{~A}$ line and $20 \mathrm{~cm} \mathrm{R}$ line and factor two was the nitrogen fertilizer levels. $\left(\mathrm{N}_{1}\right): 25 \% \mathrm{~N}$ of main crop RDF, $\left(\mathrm{N}_{2}\right): 50 \% \mathrm{~N}$ of main crop RDF, $\left(\mathrm{N}_{3}\right)$ : $75 \% \mathrm{~N}$ of main crop RDF, $\left(\mathrm{N}_{4}\right): 100 \% \mathrm{~N}$ of main crop RDF and replicated thrice. The resultant seed quality attributes were examined in the laboratory of Department of Seed Science and Technology, College of Agriculture, UAS, Dharwad. The parental seeds, CRMS 32-A (male sterile line) and MSN 36-R (Restorer line) of $\mathrm{KRH}-4$ hybrid rice were collected from the Zonal Agricultural Research Station, Mandya. The ratooning (stubble cutting) of parental lines treatments were imposed at harvest maturity stage and the nitrogen fertilizer treatments were imposed immediately after the main crop harvest in each plots as per the treatments. The five randomly selected and tagged plants from the net plot were used to record the observations. Observations on plant height $(\mathrm{cm})$, regeneration percentage, number of tillers and yield parameters like number of productive tillers, panicle length $(\mathrm{cm})$, seed set $(\%)$ and seed yield plant ${ }^{-1}(\mathrm{~g})$ were recorded. The data recorded were subjected to the statistical analysis as per Panse and Sukhatme.

\section{Results and Discussion}

Studies on influence of stubble height and nitrogen levels exhibited the significant variations on growth, flowering and yield parameters in KRH-4 hybrid seed production by ratooning of parental lines. Among the treatments of height of stubble cutting, the higher stubble heights $\left(\mathrm{H}_{3}\right): 20 \mathrm{~cm}$ in A line and $20 \mathrm{~cm}$ in $\mathrm{R}$ line recorded the significantly 
higher growth parameters like regeneration percentage (98.89\% and $98.67 \%$ in 2016 and 2017 respectively), highest plant height $(45.54 \mathrm{~cm}$ and $46.54 \mathrm{~cm}$ in 2016 and 2017 respectively), least number of days to 50 per cent flowering (42.75 and 43.92 days in 2016 and 2017 respectively), highest number of tillers (7.31 and 8.57 in 2016 and 2017 respectively), similarly among the yield parameters, the higher number of productive tillers (5.08 and 6.30 in 2016 and 2017 respectively) was noticed with $\mathrm{H}_{3}$, whereas higher seed set per cent $(8.47 \%$ and $8.68 \%$ in 2016 and 2017 respectively) and seed yield per hectare $(375 \mathrm{~kg}$ and $425 \mathrm{~kg}$ in 2016 and 2017 respectively) were registered with stubble height $\mathrm{H}_{3}$.

The nitrogen levels imparted the remarkable variations on growth, flowering and yield parameters. Among the treatments of nitrogen levels, the nitrogen dosage of $100 \%$ of the main crop $\left(\mathrm{F}_{4}\right)$ registered the significantly higher growth parameters like regeneration percentage (97.49\% and $97.53 \%$ in 2016 and 2017 respectively), highest plant height (44.50 cm and $45.61 \mathrm{~cm}$ in 2016 and 2017 respectively), whereas the least number of days to 50 per cent flowering (42.78 and 44.00 days in 2016 and 2017 respectively) was observed in the plants given with the $75 \%$ nitrogen of the main crop $\left(\mathrm{F}_{3}\right)$, similarly the nitrogen dose $\left(\mathrm{F}_{3}\right): 75$ per cent nitrogen of main crop recorded the highest number of tillers (7.43 and 8.72 in 2016 and 2017 respectively), the higher number of productive tillers (5.08 and 6.30 in 2016 and 2017 respectively), seed set per cent ( $8.37 \%$ and $8.63 \%$ in 2016 and 2017 respectively) and seed yield per hectare $(395 \mathrm{~kg}$ and $450 \mathrm{~kg}$ in 2016 and 2017 respectively).

The interaction effects were found nonsignificant for the regeneration percentage, number of tillers and seed set percent however the treatment combination of $\mathrm{H}_{3} \mathrm{~F}_{4}$ recorded significantly highest plant height (46.17 $\mathrm{cm}$ and $46.83 \mathrm{~cm}$ in 2016 and 2017 respectively), $\quad \mathrm{H}_{3} \mathrm{~F}_{3}$ interaction took significantly least number of days for 50 per cent flowering (42.33 and 43.67 days in 2016 and 2017 respectively), whereas the treatment combination of $\mathrm{H}_{2} \mathrm{~F}_{3}$ registered the highest seed yield per hectare (449 $\mathrm{kg}$ and $502 \mathrm{~kg}$ in 2016 and 2017 respectively).

Though the genotypic difference exists for the growth, performance and ratooning ability, the success of ratoon crop also depends on the agronomic practices like height of cutting, time of cutting, water and fertilizer management with care of plant protection. So in the present investigation also the ratooning practices like height of cutting and nitrogen levels vitally influence the ratoon growth and performance. The cutting height of parental lines significantly influenced the growth parameters. Among the treatments, the cutting height $\mathrm{H}_{3}: 20 \mathrm{~cm}$ in A line and $20 \mathrm{~cm}$ in $\mathrm{R}$ line recorded the highest regeneration per cent, highest plant height, least number of days 50 per cent flowering and highest number tillers compared to other stubble cutting heights. Wide variation exists among rice cultivars in their genetic potential for ratooning and yield levels. On an average, ratoon rice can give a yield roughly equivalent to 40 per cent that of the main crop, with 40 per cent reduction in crop duration. The increase in the plant height and number of tillers as well as earliness in the flowering is mainly because of higher carbohydrates that remain in the stubbles and roots (Mahadevappa and Yogeesha, 1988) in longer stubbles after the harvest of the main crop and rapid senescence of leaves in the shorter cutting heights of stubbles. Bahar and Datta (1977) observed $15-20 \mathrm{~cm}$ as the optimum cutting height above ground. The present findings are similar with the reports of Mortaza et al., (2011) in rice; Petroudi et al., (2011) in rice. 
Among the level of nitrogen fertilizers, application of 100 per cent nitrogen of main crop RDF $\left(\mathrm{F}_{4}\right)$ recorded the significantly highest regeneration per cent, accordingly highest plant height, whereas $\mathrm{F}_{3}$ recorded the higher number of tillers, least number of days to $50 \%$ flowering. The higher dosage of nitrogen fertilizer increased $\mathrm{N}$ metabolism, delayed leaf senescence and promoted germination of dormant buds. Although ratoon tiller development is determined by genotype and a number of management and environmental factors, Chauhan et al., (1985) and Ichii (1984) showed the effectiveness of nitrogen element in promoting development and growth of ratoon tillers. However the higher dose of nitrogen promotes the vegetative growth and delays the flowering. Similar results were also reported by Ali et al., (2011) in rice and Endris and Alemayehu (2014) in rice.

Ratooning in rice offers special scope for boosting the production without expanding land area, particularly where moisture and growing season are inadequate for planting a second crop of rice. The ratoon yield varies $26 \%$ to $350 \%$ of the main crop, but on an average the ratoon yield roughly equivalent to $40 \%$ that of the main crop depending upon the management practices (Chauhan, 1988). In the present study also the ratooning practices in hybrid rice seed production exigently influenced the ratoon yield and yield parameters.

The yield attributes such as number of productive tillers, seed set per cent and seed yield per hectare were found to be significant for the cutting height. Though the cutting height $\mathrm{H}_{3}: 20 \mathrm{~cm}$ in $\mathrm{A}$ line and $20 \mathrm{~cm}$ in $\mathrm{R}$ line recorded the highest number of productive tillers, the cutting height $\mathrm{H}_{2}: 15$ $\mathrm{cm}$ in A line and $20 \mathrm{~cm}$ in $\mathrm{R}$ line registered higher seed set per cent, seed yield per plant and highest seed yield per hectare. This might be due to the better synchrony of flowering between parental ratoons ensuring the effective crossing, higher seed set and seed yield compared to other cutting heights. The height of cutting affects the days to panicle emergence and days to flowering (Mahadevappa and Yogeesha, 1988; Santos et $a l ., 2003)$ as the synchrony of parental lines is the key for success in hybrid seed production the differential cutting height of $15 \mathrm{~cm}$ in the seed parent and $20 \mathrm{~cm}$ in the pollen parent facilitated the better synchrony together with optimum height for the better regeneration. Application of $75 \%$ of nitrogen of main crop registered the higher yield parameters compared to other doses of nitrogen. Availability of nitrogen to the left over stubbles just after removing main crop plant tops is important in harnessing the reserve carbohydrates accumulated in stem bases, and eventually in the better growth and development of the ratoon plant.

The higher doses of nitrogen negatively affect the mobilization of carbohydrate reserves of ratoon rice causing delay in the duration for flowering, maturity and weakening of the plants which may adversely affect the performance and yield of the ratoon rice. Similar results were given by Evatt and Beachell (1960) who recommended that application of 75 per cent nitrogen of main crop as the optimum nitrogen dosage for higher yield of ratoon. The present research findings are in agreement with the findings of Hiroshi and Satoshi (2008) in rice and Ali et al., (2011). The significantly increased yield in $\mathrm{H}_{2} \mathrm{~F}_{3}$ might be due to the effective synchrony achieved with differential cutting heights of parental lines (Mahadevappa and Yogeesha, 1988) as well as the increased yield attributing characters in the ratoon plants imposed with cutting height of $15 \mathrm{~cm}$ in A line and $20 \mathrm{~cm}$ in $\mathrm{R}$ line together with optimum dosage on nitrogen fertilizer of 75 per cent of main crop (Table 1-4). 
Table.1 Influence of stubble height and nitrogen application on regeneration per cent and plant height in seed parent (CRMS 32-A) of $\mathrm{KRH}-4$ hybrid rice

\begin{tabular}{|c|c|c|c|c|c|c|c|c|c|c|c|c|c|c|c|c|}
\hline \multirow[t]{2}{*}{ Treatments } & \multicolumn{4}{|c|}{ Regeneration per cent (2016) } & \multicolumn{4}{|c|}{ Regeneration per cent (2017) } & \multicolumn{4}{|c|}{ Plant height (cm) 2016} & \multicolumn{4}{|c|}{ Plant height (cm) 2017} \\
\hline & $\mathbf{H}_{1}$ & $\mathbf{H}_{2}$ & $\mathbf{H}_{3}$ & Mean & $\mathrm{H}_{1}$ & $\mathbf{H}_{2}$ & $\mathbf{H}_{3}$ & Mean & $\mathbf{H}_{1}$ & $\mathbf{H}_{2}$ & $\mathbf{H}_{3}$ & Mean & $\mathbf{H}_{1}$ & $\mathbf{H}_{2}$ & $\mathbf{H}_{3}$ & Mean \\
\hline $\mathbf{F}_{1}$ & 91.98 & 93.70 & 97.78 & 94.49 & 91.11 & 92.59 & 97.28 & 93.66 & 41.17 & 41.50 & 45.17 & 42.61 & 41.83 & 42.33 & 46.33 & 43.50 \\
\hline $\mathbf{F}_{2}$ & 93.83 & 94.69 & 98.40 & 95.64 & 94.07 & 94.94 & 98.02 & 95.68 & 41.83 & 42.17 & 45.33 & 43.11 & 43.33 & 43.73 & 46.33 & 44.47 \\
\hline $\mathbf{F}_{3}$ & 94.81 & 96.42 & 100.00 & 97.08 & 95.43 & 95.68 & 99.88 & 97.00 & 43.17 & 43.17 & 45.50 & 43.94 & 44.50 & 44.67 & 46.67 & 45.28 \\
\hline $\mathbf{F}_{4}$ & 96.05 & 97.04 & 99.38 & 97.49 & 96.30 & 96.79 & 99.51 & 97.53 & 43.83 & 43.50 & 46.17 & 44.50 & 45.00 & 45.00 & 46.83 & 45.61 \\
\hline \multirow[t]{2}{*}{ Mean } & 94.17 & 95.46 & 98.89 & & 94.23 & 95.00 & 98.67 & & 42.50 & 42.58 & 45.54 & & 43.67 & 43.93 & 46.54 & \\
\hline & \multicolumn{2}{|c|}{ S. Em. \pm} & \multicolumn{2}{|c|}{ CD (0.05) } & \multicolumn{2}{|c|}{ S. Em. \pm} & \multicolumn{2}{|c|}{ CD $(0.05)$} & \multicolumn{2}{|c|}{ S. Em. \pm} & \multicolumn{2}{|c|}{ CD $(0.05)$} & \multicolumn{2}{|c|}{ S. Em. \pm} & \multicolumn{2}{|c|}{ CD (0.05) } \\
\hline $\mathbf{F}$ & \multicolumn{2}{|c|}{0.68} & \multicolumn{2}{|c|}{2.00} & \multicolumn{2}{|c|}{0.65} & \multicolumn{2}{|c|}{1.92} & \multicolumn{2}{|c|}{0.15} & \multicolumn{2}{|c|}{0.45} & \multicolumn{2}{|c|}{0.21} & \multicolumn{2}{|c|}{0.61} \\
\hline H & \multicolumn{2}{|c|}{0.59} & \multicolumn{2}{|c|}{1.73} & \multicolumn{2}{|c|}{0.57} & \multicolumn{2}{|c|}{1.66} & \multicolumn{2}{|c|}{0.13} & \multicolumn{2}{|c|}{0.39} & \multicolumn{2}{|c|}{0.18} & \multicolumn{2}{|c|}{0.53} \\
\hline $\mathbf{F} \times \mathbf{H}$ & \multicolumn{2}{|c|}{1.18} & \multicolumn{2}{|c|}{ NS } & \multicolumn{2}{|c|}{1.13} & \multicolumn{2}{|c|}{ NS } & \multicolumn{2}{|c|}{0.27} & & 78 & & 36 & & 06 \\
\hline
\end{tabular}

Table.2 Influence of stubble height and nitrogen application on total tillers and productive tillers in seed parent (CRMS 32-A) of KRH-4 hybrid rice

\begin{tabular}{|c|c|c|c|c|c|c|c|c|c|c|c|c|c|c|c|c|}
\hline \multirow[t]{2}{*}{ Treatments } & \multicolumn{4}{|c|}{ Total tillers (2016) } & \multicolumn{4}{|c|}{ Total tillers (2017) } & \multicolumn{4}{|c|}{ Productive tillers (2016) } & \multicolumn{4}{|c|}{ Productive tillers (2017) } \\
\hline & $\mathrm{H}_{1}$ & $\mathbf{H}_{2}$ & $\mathbf{H}_{3}$ & Mean & $\mathbf{H}_{1}$ & $\mathbf{H}_{2}$ & $\mathbf{H}_{3}$ & Mean & $\mathrm{H}_{1}$ & $\mathbf{H}_{2}$ & $\mathbf{H}_{3}$ & Mean & $\mathrm{H}_{1}$ & $\mathbf{H}_{2}$ & $\mathbf{H}_{3}$ & Mean \\
\hline $\mathbf{F}_{1}$ & 5.37 & 5.40 & 6.43 & 5.73 & 6.50 & 6.60 & 7.57 & 6.89 & 3.53 & 3.53 & 4.33 & 3.80 & 4.67 & 4.73 & 5.53 & 4.98 \\
\hline $\mathbf{F}_{2}$ & 5.97 & 6.00 & 7.00 & 6.32 & 7.10 & 7.23 & 8.13 & 7.49 & 4.10 & 4.20 & 4.93 & 4.41 & 5.23 & 5.20 & 6.20 & 5.54 \\
\hline $\mathbf{F}_{3}$ & 7.13 & 7.17 & 8.00 & 7.43 & 8.37 & 8.43 & 9.37 & 8.72 & 5.07 & 5.17 & 5.67 & 5.30 & 6.33 & 6.43 & 6.80 & 6.52 \\
\hline $\mathbf{F}_{4}$ & 6.70 & 6.80 & 7.80 & 7.10 & 8.03 & 8.20 & 9.20 & 8.48 & 4.40 & 4.60 & 5.40 & 4.80 & 5.67 & 5.83 & 6.67 & 6.06 \\
\hline \multirow[t]{2}{*}{ Mean } & 6.29 & 6.34 & 7.31 & & 7.50 & 7.62 & 8.57 & & 4.28 & 4.38 & 5.08 & & 5.48 & 5.55 & 6.30 & \\
\hline & \multicolumn{2}{|c|}{ S. Em. \pm} & \multicolumn{2}{|c|}{ CD (0.05) } & \multicolumn{2}{|c|}{ S. Em. \pm} & \multicolumn{2}{|c|}{ CD (0.05) } & \multicolumn{2}{|c|}{ S. Em. \pm} & \multicolumn{2}{|c|}{ CD $(0.05)$} & \multicolumn{2}{|c|}{ S. Em. \pm} & \multicolumn{2}{|c|}{ CD (0.05) } \\
\hline $\mathbf{F}$ & \multicolumn{2}{|c|}{0.04} & \multicolumn{2}{|c|}{0.11} & \multicolumn{2}{|c|}{0.07} & \multicolumn{2}{|c|}{0.20} & \multicolumn{2}{|c|}{0.13} & \multicolumn{2}{|c|}{0.38} & \multicolumn{2}{|c|}{0.11} & \multicolumn{2}{|c|}{0.33} \\
\hline H & \multicolumn{2}{|c|}{0.03} & \multicolumn{2}{|c|}{0.09} & \multicolumn{2}{|c|}{0.06} & \multicolumn{2}{|c|}{0.18} & \multicolumn{2}{|c|}{0.11} & \multicolumn{2}{|c|}{0.33} & \multicolumn{2}{|c|}{0.10} & \multicolumn{2}{|c|}{0.28} \\
\hline $\mathbf{F} \times \mathbf{H}$ & \multicolumn{2}{|c|}{0.06} & \multicolumn{2}{|c|}{ NS } & \multicolumn{2}{|c|}{0.12} & \multicolumn{2}{|c|}{ NS } & \multicolumn{2}{|c|}{0.22} & & NS & & & & NS \\
\hline
\end{tabular}

F: Nitrogen levels

$\mathrm{F}_{1}: 25 \% \mathrm{~N}$ of main crop

$\mathrm{F}_{2}: 50 \% \mathrm{~N}$ of main crop

$\mathrm{F}_{3}: 75 \% \mathrm{~N}$ of main crop

$\mathrm{F}_{4}: 100 \% \mathrm{~N}$ of main crop

NS: Non-significant

\section{H: Height of cutting}

$\mathrm{H}_{1:} 15 \mathrm{~cm}$ A line and $15 \mathrm{~cm} \mathrm{R}$ line

$\mathrm{H}_{2:} 15 \mathrm{~cm}$ A line and $20 \mathrm{~cm} \mathrm{R}$ line

$\mathrm{H}_{3:}: 20 \mathrm{~cm} A$ line and $20 \mathrm{~cm} \mathrm{R}$ line 
Table.3 Influence of stubble height and nitrogen application on days to 50\% flowering and seed set per cent in seed parent (CRMS 32-A) of KRH-4 hybrid rice

\begin{tabular}{|c|c|c|c|c|c|c|c|c|c|c|c|c|c|c|c|c|}
\hline \multirow[t]{2}{*}{ Treatments } & \multicolumn{4}{|c|}{$\begin{array}{c}\text { Days to } 50 \% \text { flowering } \\
(2016)\end{array}$} & \multicolumn{4}{|c|}{$\begin{array}{c}\text { Days to } 50 \% \text { flowering } \\
(2017)\end{array}$} & \multicolumn{4}{|c|}{ Seed set per cent 2016} & \multicolumn{4}{|c|}{ Seed set per cent 2017} \\
\hline & $\mathbf{H}_{1}$ & $\mathrm{H}_{2}$ & $\mathbf{H}_{3}$ & Mean & $\mathbf{H}_{1}$ & $\mathbf{H}_{2}$ & $\mathbf{H}_{3}$ & Mean & $\mathbf{H}_{1}$ & $\mathbf{H}_{2}$ & $\mathbf{H}_{3}$ & Mean & $\mathbf{H}_{1}$ & $\mathbf{H}_{2}$ & $\mathbf{H}_{3}$ & Mean \\
\hline $\mathbf{F}_{1}$ & 45.00 & 44.67 & 43.00 & 44.22 & 46.33 & 46.00 & 44.33 & 45.56 & 7.06 & 7.84 & 7.24 & 7.38 & 7.32 & 7.97 & 7.33 & 7.54 \\
\hline $\mathbf{F}_{2}$ & 44.67 & 43.33 & 43.00 & 43.67 & 46.00 & 44.67 & 43.67 & 44.78 & 7.57 & 8.18 & 7.71 & 7.82 & 7.75 & 8.37 & 7.87 & 8.00 \\
\hline $\mathbf{F}_{3}$ & 43.00 & 43.00 & 42.33 & 42.78 & 44.33 & 44.00 & 43.67 & 44.00 & 7.98 & 9.00 & 8.13 & 8.37 & 8.14 & 9.33 & 8.42 & 8.63 \\
\hline $\mathbf{F}_{4}$ & 43.33 & 43.00 & 42.67 & 43.00 & 44.67 & 44.33 & 44.00 & 44.33 & 7.73 & 8.86 & 8.12 & 8.24 & 7.94 & 9.04 & 8.30 & 8.43 \\
\hline \multirow[t]{2}{*}{ Mean } & 44.00 & 43.50 & 42.75 & & 45.33 & 44.75 & 43.92 & & 7.59 & 8.47 & 7.80 & & 7.79 & 8.68 & 7.98 & \\
\hline & \multicolumn{2}{|c|}{ S. Em. \pm} & \multicolumn{2}{|c|}{ CD (0.05) } & \multicolumn{2}{|c|}{ S. Em. \pm} & \multicolumn{2}{|c|}{ CD (0.05) } & \multicolumn{2}{|c|}{ S. Em. \pm} & \multicolumn{2}{|c|}{ CD (0.05) } & \multicolumn{2}{|c|}{ S. Em. \pm} & \multicolumn{2}{|c|}{ CD (0.05) } \\
\hline $\mathbf{F}$ & \multicolumn{2}{|c|}{0.15} & \multicolumn{2}{|c|}{0.44} & \multicolumn{2}{|c|}{0.14} & \multicolumn{2}{|c|}{0.41} & \multicolumn{2}{|c|}{0.07} & \multicolumn{2}{|c|}{0.21} & \multicolumn{2}{|c|}{0.12} & \multicolumn{2}{|c|}{0.35} \\
\hline H & \multicolumn{2}{|c|}{0.13} & \multicolumn{2}{|c|}{0.38} & \multicolumn{2}{|c|}{0.12} & \multicolumn{2}{|c|}{0.35} & \multicolumn{2}{|c|}{0.06} & \multicolumn{2}{|c|}{0.18} & \multicolumn{2}{|c|}{0.10} & \multicolumn{2}{|c|}{0.30} \\
\hline $\mathbf{F} \times \mathbf{H}$ & \multicolumn{2}{|c|}{0.26} & \multicolumn{2}{|c|}{0.77} & \multicolumn{2}{|c|}{0.24} & \multicolumn{2}{|c|}{0.71} & \multicolumn{2}{|c|}{0.12} & & NS & & & & IS \\
\hline
\end{tabular}

Table.4 Influence of stubble height and nitrogen application on F1 seed yield per plant and F1 seed yield per ha in KRH-4 hybrid rice seed production

\begin{tabular}{|c|c|c|c|c|c|c|c|c|c|c|c|c|c|c|c|c|}
\hline Treatments & \multicolumn{4}{|c|}{ Seed yield/plant (g) 2016} & \multicolumn{4}{|c|}{ Seed yield/plant (g) 2017} & \multicolumn{4}{|c|}{ Seed yield/ha $(\mathrm{kg}) 2016$} & \multicolumn{4}{|c|}{ Seed yield/ha (kg) 2017} \\
\hline $\mathbf{F}_{1}$ & 2.69 & 3.04 & 2.73 & 2.82 & 3.00 & 3.37 & 3.01 & 3.13 & 278 & 302 & 284 & 288 & 330 & 352 & 332 & 338 \\
\hline $\mathbf{F}_{3}$ & 3.19 & 3.62 & 3.24 & 3.35 & 3.50 & 3.96 & 3.57 & 3.68 & 355 & 449 & 381 & 395 & 417 & 502 & 430 & 450 \\
\hline $\mathbf{F}_{4}$ & 3.06 & 3.43 & 3.10 & 3.20 & 3.37 & 3.71 & 3.38 & 3.49 & 355 & 430 & 378 & 388 & 411 & 477 & 425 & 438 \\
\hline Mean & \multicolumn{2}{|c|}{ S. Em. \pm} & \multicolumn{2}{|c|}{ CD (0.05) } & \multicolumn{2}{|c|}{ S. Em. \pm} & \multicolumn{2}{|c|}{ CD (0.05) } & \multicolumn{2}{|c|}{ S. Em. \pm} & \multicolumn{2}{|c|}{ CD (0.05) } & \multicolumn{2}{|c|}{ S. Em. \pm} & \multicolumn{2}{|c|}{ CD (0.05) } \\
\hline $\mathbf{F}$ & \multicolumn{2}{|c|}{0.02} & \multicolumn{2}{|c|}{0.05} & \multicolumn{2}{|c|}{0.02} & \multicolumn{2}{|c|}{0.05} & \multicolumn{2}{|c|}{5.93} & \multicolumn{2}{|c|}{17.40} & \multicolumn{2}{|c|}{5.84} & \multicolumn{2}{|c|}{17.13} \\
\hline H & \multicolumn{2}{|c|}{0.02} & \multicolumn{2}{|c|}{0.05} & \multicolumn{2}{|c|}{0.01} & \multicolumn{2}{|c|}{0.04} & \multicolumn{2}{|c|}{5.14} & \multicolumn{2}{|c|}{15.06} & \multicolumn{2}{|c|}{5.06} & \multicolumn{2}{|c|}{14.83} \\
\hline $\mathbf{F} \times \mathbf{H}$ & \multicolumn{2}{|c|}{0.03} & \multicolumn{2}{|c|}{0.09} & \multicolumn{2}{|c|}{0.03} & \multicolumn{2}{|c|}{0.09} & \multicolumn{2}{|c|}{10.27} & & .13 & & & & 66 \\
\hline
\end{tabular}

F: Nitrogen levels

$\mathrm{F}_{1}: 25 \% \mathrm{~N}$ of main crop

$\mathrm{F}_{2}: 50 \% \mathrm{~N}$ of main crop

$\mathrm{F}_{3}: 75 \% \mathrm{~N}$ of main crop

$\mathrm{F}_{4}: 100 \% \mathrm{~N}$ of main crop

NS: Non-significant

\section{H: Height of cutting}

$\mathrm{H}_{1}: 15 \mathrm{~cm} A$ line and $15 \mathrm{~cm} \mathrm{R}$ line

$\mathrm{H}_{2: 15} \mathrm{~cm} A$ line and $20 \mathrm{~cm} \mathrm{R}$ line

$\mathrm{H}_{3}: 20 \mathrm{~cm}$ A line and $20 \mathrm{~cm} \mathrm{R}$ line 
The improved yield attributing characters such as productive tillers and higher seed set due to optimum dosage of nitrogen level (75 $\%$ of main crop) accorded for the higher yields in ratoon (Ganguli and Ralwani 1954). The present findings are in agreement with the findings of Evatt and Beachell (1960) in rice; Votong (1975) in rice.

In conclusion, the present investigation inferred that the practice of ratooning by cutting the stubbles at the height of $15 \mathrm{~cm}$ in female parent and $20 \mathrm{~cm}$ in male parent of $\mathrm{KRH}-4$ hybrid rice together with application of $75 \%$ nitrogen dosage of main crop RDF is ideal to get higher seed yield.

\section{Acknowledgement}

The authors are thankful to the University of Agricultural Sciences, Dharwad (Karnataka), India for providing the necessary funds and facilities to undertake the present research work under Staff Research Project.

\section{References}

Ali, H., Ebrahim, A. and Hamid, Z. D., 2011, Management of cutting height and nitrogen fertilizer rates on grain yield and several attributes of ratoon rice (Oryza sativa L.) in Iran. World Appl. Sci. J., 15 (8): 1089-1094.

Bahar, F. A. and Datta, S. K., 1977, Prospects of increasing tropical rice production through ratooning. Agron. J., 69(4): 536-540.

Chauhan, J. S., 1988, Use of ratooning in hybrid rice. Oryza., 26: 151-154.

Endris, Y. and Alemayehu, 2014, Effect of nitrogen application on grain yield and nitrogen efficiency of rice, Asian $J$. Crop Sci., 6(3): 273-280

Evatt, N. S. and Beachell, H. M., 1960, Ratoon cropping of short season rice varieties in Texas. Int. Rice Comm.
Newsl., 9(3):1-4.

Ganguli, B. D. and Ralwani, L. L., 1954, Possibilities of growing ratoon crop of paddy and increasing its yield under irrigated conditions. Sci. Cult. 19(7): 350-351.

Hiroshi, N. and Satoshi, M., 2008, Effects of time of first harvest, total amount of nitrogen, and nitrogen application method on total dry matter yield in twice harvesting of rice. Field Crop Res., 105(2): 40-47.

Ichii, M., 1984, Studies on the utility of ratoon traits of rice as the indicator of agronomic characters in breeding. Agron. J., 69: 536-540.

Mahadevappa, M. and Yogeesha, H. S., 1988, Rice ratooning: breeding, agronomic practices, and seed production potential. Oryza., 26: 32-36.

Mortaza, N., Hemmatollah, P. and Taghi, N. N., 2011, Effect of level and time of nitrogen fertilizer application and cutting height on yield and yield component of rice ratooning. Proc. The Fourth Int. Iran Russia Conf., Iran, pp. 602-606.

Petroudi, E. R., Ghorban, N., Javad, M., Hamid, M. and Hamid, R. M., 2011, Effects of nitrogen fertilization and rice harvest height on agronomic yield indices of ratoon rice-berseem clover intercropping system. Asian J. Cr. Sci., 5(5): 566-574

Reddy, T. G., Mahadevappa, M. and Kulkarni, K. R., 1979, Ratoon cropping of rainfed rice. Int. Rice Res. Newsl., 4(5): 25-26.

Santos, A. B., Fageria, N. K. and Prabhu, A. S., 2003, Rice ratooning management practices for higher yields. Comm. Soil Sci. Plant Anal., 34: 881-918

Tarpley, L., McCauley, G. N. and Jund, M. F., 2008, Ratoon (second) crop production. In: Texas Rice Production Guidelines. Texas Agri. Life Res. Exten. 
Service, pp. 51-52.

Turner, F. T. and Jund, M. F., 1993, Rice ratoon crop yield linked to main crop stem carbohydrates. Crop Sci., 33: 150153.
Votong, V., 1975, The effect of time of drainage and time of rewatering on the yield of ratoon rice, M.Sc.(Agri.) Thesis. Univ. Sydney, (Australia).

\section{How to cite this article:}

Madhukeshwara B. Puttappanavara and Deshpande, V.K. 2019. Influence of Stubble Height and Nitrogen Fertilizer Level on Seed Yield and Quality in KRH-4 Hybrid Rice Seed Production. Int.J.Curr.Microbiol.App.Sci. 8(04): 435-442.

doi: https://doi.org/10.20546/ijcmas.2019.804.047 